Short communication

\title{
Dose response of chitosan on nutrient digestibility, blood metabolites and lactation performance in holstein dairy cows
}

\author{
R.D. Mingoti a , J.E. Freitas Jr. ${ }^{a}$, J.R. Gandra ${ }^{a}$, R. Gardinal ${ }^{a}$, G.D. Calomeni ${ }^{a}$, R.V. Barletta ${ }^{\text {a }}$, \\ T.H.A. Vendramini ${ }^{a}$, P.G. Paiva ${ }^{\text {b }}$, F.P. Rennó ${ }^{\text {a,* }}$ \\ a Department of Animal Nutrition and Production, School of Veterinary Medicine and Animal Science, University of São Paulo (USP), Av. Duque de Caxias \\ Norte, 225-Campus da USP, 13635-900 Pirassununga, SP, Brazil \\ ${ }^{\mathrm{b}}$ Department of Animal Science, UNESP - Universidade Estadual Paulista "Júlio de Mesquita Filho"/Campus Jaboticabal, Rod. Prof. Paulo Donato Castellane \\ km 5, Rural, 14884-900 Jaboticabal, SP, Brazil
}

\section{A R T I C L E I N F O}

\section{Article history:}

Received 9 June 2015

Received in revised form

23 February 2016

Accepted 25 February 2016

Keywords:

Chitosan

Digestibility

Intake

Dairy cow

\begin{abstract}
A B S T R A C T
Chitosan ( $\mathrm{CHI}$ ), a non-toxic and biodegradable biopolymer has been successfully used in the food, human and veterinary medicine industries, especially because of its antimicrobial properties. This study aimed to investigate the effects of CHI on dry matter intake (DMI), nutrient digestibility, blood metabolites, milk yield and composition, and milk fatty acids profile of lactating dairy cows. Sixteen Holstein cows $(91.3 \pm 15.1$ days in milk, $29.8 \pm 4.1 \mathrm{~kg} / \mathrm{d}$ of milk, $610 \pm 55 \mathrm{~kg}$ of body weight [BW]) were used in a $4 \times 4$ Latin square design, and each experimental period consisted of 14 days of diet adaptation and 7 days for data collection. Animals were allocated to receive one of treatments: $\mathrm{CO}$ : basal diet, without $\mathrm{CHI}$ addition; C50, C100 and C150 received 50, 100 and $150 \mathrm{mg} / \mathrm{kg}$ BW of CHI, respectively. Chitosan addition did not affect DMI, but increased $(P \leq 0.05)$ the digestibility of dry matter (DM), organic matter (OM), crude protein (CP) and neutral detergent fiber (NDF). Blood urea nitrogen concentration was increased $(P=0.01)$ with $\mathrm{CHI}$ addition. Chitosan decreased $(P=0.02)$ nitrogen $(\mathrm{N})$ fecal excretion without affect nitrogen balance. There was no effect of $\mathrm{CHI}$ on milk yield, fat corrected milk, and milk composition. Chitosan decreased $(P \leq 0.05) \mathrm{C} 6: 0$ and $\mathrm{C} 18: 1 \mathrm{c}$, and quadratically affected C14:1 fatty acids (FA) concentration in milk fat. Chitosan had no effect on total saturated and unsaturated FA of milk fat. Chitosan improved nutrient digestibility without affect productive performance and milk fatty acid profile of midlactation dairy cows.
\end{abstract}

(c) 2016 Elsevier B.V. All rights reserved.

\section{Introduction}

Currently, possible bacterial resistance with the use of antibiotics as additive to improve animal performance led to increase of the interest of scientific and industry related to the use of natural additives compounds in food preservation, human and animal health (Gois et al., 2016).

Chitosan ( $\mathrm{CHI})$ is a nontoxic and biodegradable biopolymer that has received attention due to its potential application in human and veterinary medicine and food preservation, notably for its properties against bacteria, fungi and yeasts (Kong et al., 2010). However, the use of $\mathrm{CHI}$ as an animal feed additive has been poorly explored, with few studies in non-ruminant digestion aiming to improve nitrogen retention, feed efficiency, and performance

\footnotetext{
* Corresponding author.

E-mail address: francisco.renno@usp.br (F.P. Rennó).
}

(Huang et al., 2005; Xu et al., 2013).

In ruminant nutrition, several studies had showed that $\mathrm{CHI}$ could change ruminal fermentation, including higher propionate concentration and lower acetate to propionate ratio, likely improving the energy efficiency of ruminal fermentation (Goiri et al., 2009a; Goiri et al., 2010a). However, in vitro studies reported that $\mathrm{CHI}$ decreased dry matter (DM) digestibility, especially in high fiber mixtures in batch cultures (Goiri et al., 2009a; Goiri et al. 2009b). On the other hand, CHI was effective to inhibit biohydrogenation by increasing C18:1, t11 fatty acid (FA) and total conjugated linoleic acid (CLA) proportions and decreasing the saturated FA proportion an in vitro conditions (Goiri et al., 2010b); and currently, there are few studies evaluating the effects of $\mathrm{CHI}$ in vivo. Therefore, the objective of this study was to evaluate the effects of CHI on dry matter intake (DMI), nutrient digestibility, blood metabolites, nitrogen balance, milk yield and composition, and milk fatty acids profile of lactating dairy cows. 


\section{Materials and methods}

The Ethics Committee of the School of Veterinary Medicine and Animal Science of the University of Sao Paulo, approved the experimental procedures (approval number 2222/2011).

\subsection{Animals, design and treatments}

Sixteen Holstein cows were used that averaged $91.3 \pm 15.1$ days in milk, $610 \pm 55 \mathrm{~kg}$ of BW; $29.8 \pm 4.1 \mathrm{~kg} / \mathrm{d}$ of milk yield at the beginning of the trial. Cows were housed in individual pens with $17.5 \mathrm{~m}^{2}$, sand beds and forced ventilation. Each experimental period consisted of 14 days of diet adaptation and 7 days for data collection. The cows were allocated into a replicate $4 \times 4$ Latin square design to receive one of four treatments: C0: basal diet, without chitosan addition; C50, C100 and C150 received 50, 100 and $150 \mathrm{mg} / \mathrm{kg}$ BW chitosan, respectively. Chitosan was provided daily to cows into two equal portions, weighed and top dressed to the total mixed ration before the morning and afternoon feeding, and cows were fed twice daily $(0700 \mathrm{~h}$ and $1300 \mathrm{~h})$ to maintain refusals between $5 \%$ and $10 \%$ (on as fed basis). Chitosan used in this study had $0.33 \mathrm{~g} / \mathrm{mL}$ of apparent density, $\mathrm{pH}$ of 8.81 , and deacetylation degree of $86.6 \%$ (Polymar ${ }^{\circledR}$ Science and Nutrition, Fortaleza, Ceara, Brazil). Basal control diet was formulated to meet requirement of lactating dairy cows producing $30.0 \mathrm{~kg} / \mathrm{d}$ of milk yield with $3.5 \%$ of fat according to the recommendations of NRC (2001). Basal control diet consisted of $50 \%$ of corn silage, $23.73 \%$ of ground corn, $14.50 \%$ of soybean meal, $8.01 \%$ of whole raw soybeans, $0.35 \%$ of urea, $0.10 \%$ of ammonium sulfate, $0.80 \%$ of sodium bicarbonate, $0.09 \%$ of magnesium oxide, $0.14 \%$ of limestone, $0.24 \%$ of salt, and $1.98 \%$ of mineral premix ( $190 \mathrm{~g} / \mathrm{kg}$ of $\mathrm{Ca}, 73 \mathrm{~g} / \mathrm{kg}$ of $\mathrm{P}$, $44 \mathrm{~g} / \mathrm{kg}$ of $\mathrm{Mg}, 30 \mathrm{~g} / \mathrm{kg}$ of S, $340 \mathrm{mg} / \mathrm{kg}$ of $\mathrm{Cu} ; 1350 \mathrm{mg} / \mathrm{kg}$ of $\mathrm{Zn}$, $940 \mathrm{mg} / \mathrm{kg}$ of $\mathrm{Mn}, 16 \mathrm{mg} / \mathrm{kg}$ of I, $3 \mathrm{mg} / \mathrm{kg}$ of Co, $100 \mathrm{mg} / \mathrm{kg}$ of Se, $1064 \mathrm{mg} / \mathrm{kg}$ of Fe, 10,000 UI of vitamin-A, $4000 \mathrm{UI}$ of vitamin-D, and $6000 \mathrm{UI}$ of vitamin-E) on DM basis (Supplementary data). Throughout the experiment, BW and body condition score (BCS) were measured at the first and day 21 of each period after the morning milking.

\subsection{Data and sample collection}

Samples of feed and orts were collected throughout the sampling period and stored at $-20^{\circ} \mathrm{C}$ until analyses. During days $16-$ 18 of each experimental period, fecal samples were collected from each cow, after a.m. and p.m. milking, comprising a composite sample per cow. Samples of feeds, orts and feces were dried in a $65{ }^{\circ} \mathrm{C}$ forced-air oven for $72 \mathrm{~h}$, ground to pass through a $1 \mathrm{~mm}$ screen (Thomas Wiley Mills, Thomas Scientific, Swedesboro, USA) and analyzed for dry matter (DM) (method 930.15; Association of official Analytical Chemists, 2000), crude protein (CP) $(\mathrm{N} \times 6.25$; method 984.13; Association of official Analytical Chemists, 2000), ether extract (EE) (method 920.39; Association of official Analytical Chemists, 2000), acid detergent fiber (ADF) (method 973.18; Association of official Analytical Chemists, 2000), ash (method 942.05; Association of official Analytical Chemists, 2000). Neutral detergent fiber (NDF) was analyzed according to Mertens (2002), using thermo-stable alpha-amylase without addition of sodium sulfite to detergent (Ankom Technology, Macedon, USA).

Indigestible acid-detergent fiber (iADF) was used as an internal marker to estimate fecal excretion and apparent total-tract digestibility of nutrients. Dried samples of feeds, refusals and feces were processed in a Wiley mill through a $2 \mathrm{~mm}$ screen (Thomas Wiley Mills, Thomas Scientific, Swedesboro, USA). These samples were placed in bags of non-woven textile $\left(100 \mathrm{~g} \mathrm{~m}^{-2}\right)$ following the recommendation of a maximum of $20 \mathrm{mg}$ of $\mathrm{DM} / \mathrm{cm}^{2}$ (Nocek, 1988), and then incubated for $288 \mathrm{~h}$ in the rumen of two Holstein cows previously adapted to a similar diet used in this study according to Casali et al. (2008). After the removal from rumen, bags were washed in running tap water, dried at $65^{\circ} \mathrm{C}$ in a forced-air oven and submitted to acid-detergent solution in an Ankom ${ }^{\circledR}$ System (Ankom Technology, Macedon, USA) to obtain the iADF concentrations as previously described.

\subsection{Milk production, composition and fatty acid profile}

Cows were mechanically milked twice daily at 0600 and $1600 \mathrm{~h}$, and milk production was measured by an automatic milk meter $\left(\right.$ Alpro $^{\circledR}$, DeLaval - Tumba, Sweden). Milk samples were collected from each cow on days 16, 17 and 18 of the experimental period and then analyzed for $\mathrm{CP}$, fat, and lactose (Milkoscan; Foss Eletric, Hillerod - Denmark). Milk yield were corrected for 3.5\% of fat according to Sklan et al. (1992).

Milk FA extraction was performed according to Feng et al. (2004) and separated fat was methylated according to Kramer et al. (1997). Fatty acids were quantified by gas chromatography (GC Shimatzu 2010, Shimadzu Corporation, Kyoto - Japan) using an SP-2560 capillary column $(100 \mathrm{~m} \times 0.25 \mathrm{~mm}$ i.d. with $0.02-\mu \mathrm{m}$ film thickness; Supelco Sigma-Aldrich Group, Bellefonte, Pennsylvania, USA). The oven temperature was $70^{\circ} \mathrm{C}$ for $4 \mathrm{~min}$, increased $13^{\circ} \mathrm{C} / \mathrm{min}$ to $175^{\circ} \mathrm{C}$, and then held at this temperature for $27 \mathrm{~min}$. Finally, temperature was increased by $4^{\circ} \mathrm{C} / \mathrm{min}$ until reached $215^{\circ} \mathrm{C}$, and kept for $31 \mathrm{~min}$. Hydrogen was used as the carrier gas flowing at $40 \mathrm{~cm}^{3} / \mathrm{s}$. Four standards were used for FA identification: standard C4-C24 FA (TM 37; Supelco Sigma-Aldrich Group, Bellefonte, Pennsylvania, USA), C18:1 trans-11 FA (V0381G; Supelco Sigma-Aldrich Group, Bellefonte, Pennsylvania, USA), C18:2 trans-10, cis-12 FA (UC-61M $100 \mathrm{mg}$; NU-CHEKPREP, Inc. Elysian, Minnesota, USA), and C18:2 cis-9, trans-11 FA (UC-60M $100 \mathrm{mg}$; NU-CHEKPREP, Inc. Elysian, Minnesota, USA).

\subsection{Nitrogen balance, microbial protein synthesis and blood metabolites}

The daily urine volume was estimated using the creatinine concentration $(\mathrm{mg} / \mathrm{L})$ in spot urine sample, obtained four hours after the morning feeding on days 16 and 17. Creatinine concentrations were analyzed using a biochemical colorimetric kit (kinetic creatinine: cat. no. K-067, Bioclin, Belo Horizonte, Brazil) and a semiautomatic spectrophotometer (SBA 200, CELM, São Caetano do Sul, Brazil). A daily creatinine excretion rate of $24.05 \mathrm{mg} / \mathrm{kg}$ of BW was assumed (Chizzotti et al., 2008). The total excretion of uric acid (uric acid stable liquid: cat. no. K-052, Bioclin, Belo Horizonte, Brazil; determined in a semi-automatic spectrophotometer SBA 200, CELM, São Caetano do Sul, Brazil). The excretion of uric acid, allantoin in the urine and milk were considered as the total excretion of purine derivatives, and microbial protein synthesis was estimated from these concentrations according to Chen and Gomes (1992). The total nitrogen in urine samples was determined (method 984.13; Association of official Analytical Chemists, 2000) and the $\mathrm{N}$ balance was determined using the model of NRC (2001).

Blood samples were collected on the day 15 by puncture of the coccygeal vein, before the morning feeding. Serum was obtained by centrifugation of the samples at $3000 \mathrm{~g}$ for $10 \mathrm{~min}$. The blood urea nitrogen (BUN) was analyzed with commercially colorimetric kits (urea: cat. no. K-056; Bioclin ${ }^{\circledR}$, Belo Horizonte, Brazil), and reading was performed using a semi-automatic spectrophotometer (SBA 200, CELM, São Caetano do Sul, Brazil).

\subsection{Statistical analysis}

Data were analyzed with PROC MIXED (Statistical Analysis System for Windows 9.3, SAS Institute Inc., Cary, USA), according 
to the following statistical model:

$Y_{i k l m}=\mu+C_{i}+P_{k}+S_{l}+A_{m}\left(S_{l}\right)+e_{i k l m}$

where $Y_{i k l m}$ was the observed value in the animal $\mathrm{m}$, from $i$ square, in the $k$ th period, $\mu=$ overall mean; $C_{i}$ was the fixed effect of chitosan; $P_{k}$ was the fixed effect of experimental period; $S_{l}$ was the fixed effect of the Latin square; $A_{m}\left(S_{l}\right)$ was the random effect of animal within square; and $e_{i k l m}$ was the random residual error. The degrees of freedom were calculated according to Satterthwaite's method (ddfm=satterth). Response to chitosan was tested with linear and quadratic contrasts, and difference were considered significant at $P \leq 0.05$.

\section{Results}

There was no effect of CHI on DMI, either in absolute value $(\mathrm{kg} /$ d) or relative to BW $(P>0.05$; Table 1$)$. The addition of $\mathrm{CHI}$ linearly increased $(P=0.01)$ apparent total-tract digestibility of $\mathrm{CP}$, and quadratically affected $(P<0.05)$ DM, OM and NDF digestibility. Nitrogen intake, $\mathrm{N}$ excretion in urine and in milk, and $\mathrm{N}$ balance were not affected by treatments $(P>0.05)$. However, $\mathrm{N}$ fecal excretion was linearly decreased by $\mathrm{CHI}(P=0.02)$. Chitosan addition had a quadratic effect $(P=0.04)$ on $\mathrm{N}$ efficiency ( $\mathrm{N}$ milk: $\mathrm{N}$ intake), and linearly increased $(P=0.01)$ blood urea nitrogen. Microbial protein synthesis was similar among treatments $(P>0.05)$.

Increasing doses of $\mathrm{CHI}$ did not affect milk yield, fat corrected milk, fat and protein production or content $(P>0.05$; Table 2$)$. However, milk urea nitrogen (MUN) was linearly increased as $\mathrm{CHI}$ addition increased $(P<0.05)$. Body weight and BCS were not affected by $\mathrm{CHI}$ levels $(P>0.05)$. Chitosan linearly decreased $(P<0.05)$ C6 and C18:1 c9 FA, and quadratically affected C14:1 FA concentration in milk fat (Table 3 ). Nevertheless, there was no effect of $\mathrm{CHI}$ on $<\mathrm{C} 16, \mathrm{C} 16,>\mathrm{C} 16$ total FA concentrations in milk fat $(P>0.05)$. Total of $\mathrm{C} 18$ saturated, unsaturated and unsaturated to saturated FA ratio were similar among treatments $(P>0.05)$.

Table 1

Dry matter intake, apparent total-tract digestibility and nitrogen balance in dairy cows supplemented with chitosan.

\begin{tabular}{|c|c|c|c|c|c|c|c|}
\hline \multirow[t]{2}{*}{ Item } & \multicolumn{4}{|c|}{ Treatments $^{\mathrm{a}}$} & \multirow[t]{2}{*}{$\mathrm{SEM}^{\mathrm{b}}$} & \multicolumn{2}{|c|}{$P$-value ${ }^{c}$} \\
\hline & $\mathrm{CO}$ & $\mathrm{C} 50$ & C100 & C150 & & LIN & QUA \\
\hline $\begin{array}{l}\text { Dry matter intake, } \\
\mathrm{kg} / \mathrm{d}\end{array}$ & 24.49 & 24.82 & 24.26 & 24.07 & 0.44 & 0.34 & 0.55 \\
\hline $\begin{array}{l}\text { Dry matter intake, } \\
\% \text { BW }\end{array}$ & 3.96 & 4.01 & 3.92 & 3. 89 & 0.07 & 0.37 & 0.56 \\
\hline \multicolumn{8}{|c|}{ Total tract apparent digestibility (\%) } \\
\hline Dry matter & 67.22 & 70.91 & 69.51 & 69.35 & 0.70 & 0.28 & 0.05 \\
\hline Organic matter & 67.99 & 71.88 & 70.61 & 70.06 & 0.81 & 0.25 & 0.03 \\
\hline Crude protein & 78.79 & 80.92 & 81.29 & 81.53 & 0.57 & 0.01 & 0.18 \\
\hline $\begin{array}{l}\text { Neutral detergent } \\
\text { fiber }\end{array}$ & 56.44 & 62.13 & 60.28 & 58.84 & 0.93 & 0.36 & 0.01 \\
\hline \multicolumn{8}{|l|}{ Nitrogen balance } \\
\hline $\mathrm{N}$ intake, $\mathrm{g} / \mathrm{d}$ & 645.33 & 655.07 & 639.83 & 638.45 & 10.8 & 0.47 & 0.61 \\
\hline $\mathrm{N}$ urinary, $\mathrm{g} / \mathrm{d}$ & 283.73 & 300.28 & 289.03 & 290.40 & 5.48 & 0.76 & 0.24 \\
\hline $\mathrm{N}$ fecal, $\mathrm{g} / \mathrm{d}$ & 137.36 & 126.37 & 120.39 & 120.48 & 4.52 & 0.02 & 0.31 \\
\hline $\mathrm{N}$ milk, g/d & 142.23 & 141.20 & 141.59 & 147.44 & 2.21 & 0.24 & 0.26 \\
\hline $\mathrm{N}$ balance, $\mathrm{g} / \mathrm{d}$ & 82.14 & 87.55 & 88.55 & 80.00 & 84.5 & 0.82 & 0.21 \\
\hline $\mathrm{N}$ milk: $\mathrm{N}$ intake & 22.3 & 21.7 & 22.4 & 23.4 & 0.39 & 0.03 & 0.04 \\
\hline $\mathrm{BUN}^{\mathrm{d}}, \mathrm{mg} / \mathrm{dL}$ & 38.59 & 40.16 & 41.94 & 44.35 & 1.05 & 0.01 & 0.79 \\
\hline $\begin{array}{l}\text { Microbial protein, } \\
\text { g/d }\end{array}$ & 1818.6 & 1860.1 & 1776.6 & 1766.2 & 36.2 & 0.33 & 0.64 \\
\hline
\end{tabular}

${ }^{\text {a }} \mathrm{CO}=$ control treatment, without chitosan (CHI) addition; $\mathrm{C} 50, \mathrm{C} 100$ and $\mathrm{C} 150=$ supplemented of 50,100 and $150 \mathrm{mg} / \mathrm{kg}$ of body weight (BW) chitosan, respectively.

${ }^{\mathrm{b}} \mathrm{SEM}=$ standard error of the mean.

${ }^{c}$ LIN and QUA = probability for linear and quadratic effect, respectively.

${ }^{\mathrm{d}}$ Blood urea nitrogen.
Table 2

Milk yield and composition of dairy cows supplemented with increasing doses of chitosan.

\begin{tabular}{|c|c|c|c|c|c|c|c|}
\hline \multirow[t]{2}{*}{ Item } & \multicolumn{4}{|c|}{ Treatments $^{\mathrm{a}}$} & \multirow[t]{2}{*}{$\mathrm{SEM}^{\mathrm{b}}$} & \multicolumn{2}{|c|}{$P$-value ${ }^{\mathrm{c}}$} \\
\hline & $\mathrm{CO}$ & C50 & C100 & $\mathrm{C} 150$ & & LIN & QUA \\
\hline Milk yield, kg/d & 29.71 & 29.38 & 29.46 & 29.85 & 0.51 & 0.73 & 0.27 \\
\hline 3.5\% FCM ${ }^{\mathrm{d}}, \mathrm{kg} / \mathrm{d}$ & 26.11 & 26.23 & 27.00 & 27.31 & 0.55 & 0.12 & 0.88 \\
\hline Fat, kg/d & 0.82 & 0.83 & 0.87 & 0.89 & 0.02 & 0.16 & 0.91 \\
\hline Protein, kg/d & 0.90 & 0.89 & 0.90 & 0.94 & 0.01 & 0.28 & 0.25 \\
\hline Fat, \% & 2.75 & 2.86 & 2.98 & 2.97 & 0.08 & 0.19 & 0.65 \\
\hline Protein, \% & 3.07 & 3.08 & 3.06 & 3.16 & 0.02 & 0.25 & 0.35 \\
\hline $\mathrm{MUN}^{\mathrm{e}}, \mathrm{mg} / \mathrm{dL}$ & 8.20 & 8.59 & 8.63 & 10.33 & 0.25 & $<0.01$ & 0.15 \\
\hline Body weight, kg & 616 & 632 & 604 & 614 & 7.26 & 0.29 & 0.70 \\
\hline $\mathrm{BCS}^{\mathrm{f}}$ & 2.7 & 2.7 & 2.7 & 2.7 & 0.05 & 0.69 & 0.24 \\
\hline
\end{tabular}

${ }^{a} \mathrm{CO}=$ control treatment, without chitosan (CHI) addition; $\mathrm{C} 50, \mathrm{C} 100$ and $\mathrm{C} 150=$ supplemented with 50,100 and $150 \mathrm{mg} / \mathrm{kg}$ of body weight (BW) of chitosan, respectively.

${ }^{\mathrm{b}} \mathrm{SEM}=$ standard error of the mean.

${ }^{c}$ LIN and QUA = probability for linear and quadratic effects, respectively.

${ }^{\mathrm{d}} \mathrm{FCM}=$ fat corrected milk

e Milk urea nitrogen.

${ }^{\mathrm{f}}$ Body condition score (1-5).

Table 3

Milk fatty acids profile of dairy cows supplemented with increasing doses of chitosan.

\begin{tabular}{|c|c|c|c|c|c|c|c|}
\hline \multirow[t]{2}{*}{ Item } & \multicolumn{4}{|l|}{ Treatments $^{\mathrm{a}}$} & \multirow[t]{2}{*}{ SEM $^{\mathrm{b}}$} & \multicolumn{2}{|c|}{$P$-value ${ }^{\mathrm{c}}$} \\
\hline & $\mathrm{CO}$ & c50 & C100 & $\mathrm{C} 150$ & & LIN & QUA \\
\hline Fatty acid & $\begin{array}{l}\mathrm{g} / 100 \mathrm{~g} \text { total } \\
\text { fatty acids }\end{array}$ & & & & & & \\
\hline $4: 0$ & 0.93 & 0.76 & 0.99 & 0.66 & 0.07 & 0.33 & 0.55 \\
\hline $6: 0$ & 1.55 & 1.40 & 1.50 & 1.18 & 0.04 & 0.01 & 0.33 \\
\hline $8: 0$ & 1.18 & 1.13 & 1.12 & 1.09 & 0.02 & 0.12 & 0.73 \\
\hline $10: 0$ & 2.91 & 2.89 & 2.77 & 2.89 & 0.06 & 0.71 & 0.58 \\
\hline $11: 0$ & 0.29 & 0.27 & 0.21 & 0.24 & 0.01 & 0.11 & 0.34 \\
\hline $12: 0$ & 3.40 & 3.34 & 3.19 & 3.40 & 0.07 & 0.84 & 0.39 \\
\hline $13: 0$ & 0.11 & 0.13 & 0.11 & 0.12 & 0.01 & 0.83 & 0.64 \\
\hline $14: 0$ & 11.13 & 10.91 & 10.64 & 11.43 & 0.13 & 0.59 & 0.06 \\
\hline $14: 1$ & 0.54 & 0.51 & 0.53 & 0.58 & 0.01 & 0.06 & 0.02 \\
\hline $15: 0$ & 0.14 & 0.16 & 0.15 & 0.15 & 0.01 & 0.45 & 0.59 \\
\hline $16: 0$ & 29.62 & 30.16 & 29.39 & 31.90 & 0.49 & 0.07 & 0.18 \\
\hline $16: 1$ cis & 0.97 & 0.98 & 0.88 & 0.95 & 0.02 & 0.19 & 0.41 \\
\hline $17: 0$ & 0.25 & 0.27 & 0.26 & 0.27 & 0.01 & 0.22 & 0.73 \\
\hline $17: 1$ & 0.10 & 0.08 & 0.08 & 0.09 & 0.01 & 0.74 & 0.49 \\
\hline $18: 0$ & 13.50 & 13.97 & 14.72 & 13.47 & 0.33 & 0.79 & 0.13 \\
\hline 18:1 trans- 11 & 0.39 & 0.41 & 0.47 & 0.44 & 0.01 & 0.11 & 0.37 \\
\hline $18: 1$ cis-9 & 24.04 & 23.28 & 23.51 & 21.68 & 0.41 & 0.04 & 0.46 \\
\hline $18: 2 \mathrm{n}-6$, cis & 2.96 & 3.10 & 2.98 & 3.05 & 0.06 & 0.68 & 0.63 \\
\hline $18: 3$ & 0.13 & 0.14 & 0.14 & 0.14 & 0.01 & 0.29 & 0.95 \\
\hline $20: 0$ & 0.11 & 0.10 & 0.12 & 0.10 & 0.01 & 0.60 & 0.41 \\
\hline $20: 1$ & 0.20 & 0.20 & 0.19 & 0.19 & 0.01 & 0.22 & 0.79 \\
\hline Other & 5.27 & 6.25 & 5.68 & 5.55 & 0.13 & 0.80 & 0.02 \\
\hline \multicolumn{8}{|l|}{ Total } \\
\hline$<\mathrm{C} 16$ & 22.21 & 21.55 & 21.59 & 21.45 & 0.37 & 0.50 & 0.72 \\
\hline C16 & 30.61 & 31.17 & 30.27 & 32.90 & 0.48 & 0.08 & 0.17 \\
\hline$>\mathrm{C} 16$ & 41.80 & 41.50 & 42.37 & 40.19 & 0.73 & 0.48 & 0.44 \\
\hline \multicolumn{8}{|l|}{ C18 } \\
\hline Unsaturated C18 & 27.52 & 26.90 & 27.08 & 25.28 & 0.45 & 0.06 & 0.45 \\
\hline Saturated C18 & 13.50 & 13.97 & 14.72 & 13.47 & 0.33 & 0.79 & 0.13 \\
\hline $\begin{array}{l}\text { Unsaturated: satu- } \\
\text { rated C18 }\end{array}$ & 2.06 & 1.96 & 1.89 & 2.00 & 0.04 & 0.48 & 0.21 \\
\hline \multicolumn{8}{|l|}{ Total } \\
\hline Unsaturated & 29.28 & 28.67 & 28.79 & 27.04 & 0.46 & 0.06 & 0.46 \\
\hline Saturated & 65.15 & 65.55 & 65.66 & 66.61 & 0.52 & 0.30 & 0.72 \\
\hline $\begin{array}{l}\text { Unsaturated: } \\
\text { saturated }\end{array}$ & 0.45 & 0.44 & 0.44 & 0.40 & 0.01 & 0.09 & 0.46 \\
\hline
\end{tabular}

${ }^{\text {a }} \mathrm{CO}=$ control treatment, without chitosan (CHI) addition; $\mathrm{C} 50, \mathrm{C} 100$ and $\mathrm{C} 150=$ supplemented with 50,100 and $150 \mathrm{mg} / \mathrm{kg}$ of body weight (BW) of chitosan, respectively.

b $\mathrm{SEM}=$ standard error of the mean.

${ }^{\mathrm{c}}$ LIN and QUA = probability for linear and quadratic effects, respectively. 
Furthermore, $\mathrm{CHI}$ had no effect $(P>0.05)$ on total saturated and unsaturated FA concentration in milk.

\section{Discussion}

This study was aimed to evaluate the effects of $\mathrm{CHI}$ on feed intake, nutrient digestibility and performance in lactating dairy cows. In the current study, changes in digestibility of DM and NDF occurred, but they were not sufficient to alter DMI. Previous studies with increasing doses of CHI reported similar results, with improved nutrient digestibility without affect DMI (Araújo et al., 2015; Paiva et al., 2016) and the effects are probably related to altered ruminal fermentation.

Apparent total-tract digestibility of DM, CP and NDF improved when $\mathrm{CHI}$ was added to diet, in the current experiment. Similar results were observed when $\mathrm{CHI}$ was supplied to beef steers (Araújo et al., 2015). However, in vitro studies reported negative effects of CHI including decreased DM and NDF digestibility, especially in high-fiber mixtures in batch cultures (Goiri et al., 2009a, 2009b). Moreover, in an in vivo study with sheep, CHI tended to decrease NDF digestibility but without affect OM digestibility (Goiri et al., 2010a). The CHI mechanism of action is still not clear, but ionic interactions between positively charged bacterial surface chitosan amino group and negatively charged in the surface of bacterial, resulting in alteration of membrane permeability, has been the most acceptable theory (Helander et al., 2001; Kong et al., 2010). Zhong et al. (2008) reported that Gram-positive bacteria are more susceptible to derivatives of $\mathrm{CHI}$ as a consequence of the Gram-negative outer membrane barrier. The increase in protein digestibility could be related to the action of $\mathrm{CHI}$ on bacteria which promote proteolysis and deamination, resulting in a decrease of ruminal protein degradation and increasing amino acids availability in the intestine, a similar effect of ionophores (Russell and Martin, 1984; Yang and Russell, 1993). Thus, we suggest that the increase of the nutrient digestibility with $\mathrm{CHI}$ addition its due its capacity to change rumen microorganisms and digestive processes, acting mainly on the Gram-positive bacteria, that is justified by improvement in NDF and CP digestibility.

In the current study, $\mathrm{CHI}$ had increased BUN and milk urea nitrogen, and reduced $\mathrm{N}$ fecal excretion without affecting $\mathrm{N}$ balance and microbial protein synthesis. This fact can be related to the increase in protein digestibility, associated with the hepatic metabolism of nitrogen compounds together with urinary and fecal excretion (Jonker et al., 1998; Spek et al., 2013), leading to urea accumulation in the serum of these animals and consequently excreted in the milk. Moreover, Garcia-Rodriguez et al. (2011) reported increased BUN of sheep supplemented with $\mathrm{CHI}$, which may be related to higher degradability of protein in the rumen. In this study, the reduction of $\mathrm{N}$ fecal excretion with $\mathrm{CHI}$ supplementation is likely due to the better utilization of nitrogen in amino acids available in the small intestine resulting from changes in rumen fermentation caused by $\mathrm{CHI}$, which is related to improvement in protein digestibility. Therefore, when protein from feed is more digestible than those from microbial origin, amino acid uptake by the small intestine may be increased (McGuffey et al., 2001; Ruiz et al., 2001).

Milk production and composition were not affected by $\mathrm{CHI}$, which could be related to DMI that was not affected in this study; thus, these findings indicate that supply of nutrients to cows and especially to mammary gland was not limited. Paiva et al. (2016) reported that $\mathrm{CHI}$ increased milk yield and this effect was related to improvements in nutrient digestibility and ruminal fermentation, especially by increasing ruminal propionate which led to greater energy available for milk production.

Few milk FA were affected by CHI (C6:0; C14:1 and C18:1 c9) in the current study. However, in an in vitro study $\mathrm{CHI}$ decreased total C18:0 and increased total C18:1, C18:1 t11, total CLA, and the C18 unsaturated to saturated FA ratio (Goiri et al., 2010b). Milk FA are derived almost equally from two sources, the feed and the microbial activity on the rumen (Parodi, 2004). According to Goiri et al. 2010b), CHI could be interacting with negatively charged free FA, thereby preventing the biohydrogenation process, and/or could be affecting certain microbial population's growth. Another reason which may explain the absence of CHI effects on FA biohydrogenation in the current study is the level of EE in the diet (4.23\%) and major FA source (whole raw soybean) used. Goiri et al. (2010b) used rapeseed and sunflower meals as FA sources, which can release FA in the rumen more easily compared to whole raw soybean. Indeed, in high fat diets the content of free FA is quickly biohydrogenated in the rumen due to faster action of lipases, turning free FA available to hydrogen addition that leads to formation of CLA isomers (Doreau, 2011). Thus, our results suggest that $\mathrm{CHI}$ promote changes in the ruminal fermentation without alter milk FA profile when oilseeds was used as the dietary FA source.

\section{Conclusion}

Chitosan improved nutrient digestibility without altering productive performance and milk fatty acid profile in mid-lactation dairy cows. The results indicate that better doses of chitosan inclusion are between 100 and $150 \mathrm{mg} / \mathrm{kg} \mathrm{BW}$.

\section{Conflict of interest statement}

None authors of this manuscript has declared any conflict of interest statement.

\section{Acknowledgments}

Authors acknowledge the University of São Paulo (USP) and Dairy Cattle Research Laboratory for providing the physical infrastructure and staff necessary for this study. In addition, authors express appreciation to São Paulo Research Foundation for financial support (FAPESP; Grants \# 2011/05498-1; \# 2011/019677).

\section{Appendix A. Supplementary material}

Supplementary data associated with this article can be found in the online version at http://dx.doi.org/10.1016/j.livsci.2016.02.008.

\section{References}

Association of Official Analytical Chemists, 2000. Official Methods of Analysis, 17th ed. AOAC International, Arlington, VA.

Araújo, A.P.C., Venturelli, B.C., Santos, M.C.B., Gardinal, R., Cônsolo, N.R.B., Calomeni, G.D., Freitas, J.E., Barletta, R.V., Gandra, J.R., Paiva, P.G., Rennó, F.P., 2015. Chitosan affects total nutrient digestion and ruminal fermentation in Nellore steers. Anim. Feed Sci. Technol. 206, 114-118. http://dx.doi.org/10.1016/j. anifeedsci.2015.05.016.

Casali, A.O., Detmann, E., Valadares Filho, S.C., Pereira, J.C., Henriques, L.T., Freitas, S G., Paulino, M.F., 2008. Influence of incubation time and particles size on indigestible compounds contents in cattle feeds and feces obtained by in situ procedures. Rev. Bras. Zootec. 37, 335-342.

Chen, X.B., Gomes, M.J., 1992. Estimation of Microbial Protein Supply to Sheep and Cattle Based on Urinary Excretion of Purine Derivatives - An Overview of Technical Details. International Feed Research Unit, Rowett Research Institute, Bucksburnd, Aberdeen, p. 21. 
Chizzotti, M.L., Valadares Filho, S.C., Valadares, R.F.D., Chizzotti, F.H.M., Tedeschi, L. O., 2008. Determination of creatinine excretion and evaluation of spot urine sampling in Holstein cattle. Livest. Sci. 113, 218-225.

Doreau, M., 2011. Ruminal bio-hydrogenation of fatty acids. In: Proceedings of International Symposium on Advances in Techniques in Ruminant Nutrition Research. pp. 46-58.

Feng, S., Lock, A.L., Garnsworthy, P.C., 2004. Technical note: a rapid lipid separation method for determining fatty acid composition of milk. J. Dairy Sci. 87, 3785-3788.

Garcia-Rodriguez, A., Mandaluniz, N., Arranz, J., Goiri, I., 2011. Inclusion of chitosan in the diet of dairy ewes in early lactation. In: Proceedings of Asociación Interprofesional para el Desarrollo Agrario. XIV Jornadas sobre Producción Animal, Zaragoza, España. pp. 222-224.

Goiri, I., Oregui, L.M., Garcia-Rodriguez, A., 2009a. Dose-response effects of chitosans on in vitro rumen digestion and fermentation of mixtures differing in forage-to-concentrate ratios. Anim. Feed Sci. Technol. 151, 215-227.

Goiri, I., Garcia-Rodriguez, A., Oregui, L.M., 2009b. Effect of chitosan on mixed ruminal microorganism fermentation using the rumen simulation technique. Anim. Feed Sci. Technol. 152, 92-102.

Goiri, I., Oregui, M., Garcia-Rodriguez, A., 2010a. Use of chitosans to modulate ruminal fermentation of 50:50 forage-to-concentrate in diet sheep. J. Anim. Sci. $88,749-755$.

Goiri, I., Induraina, G., Insaustib, K., Sarriesb, V., Garcia-Rodriguez, A., 2010b. Ruminal biohydrogentation of unsaturated fatty acids in vitro as affected by chitosan. Anim. Feed Sci. Technol. 159, 35-40.

Gois, F.D., Cairo, P.L.G., Cantarelli, V.S., Costa, L.C.B., Fontana, R., Allaman, I.B., Sbardella, M., Carvalho Jr., F.M., Costa, L.B., 2016. Effects of Brazilian red pepper (Schinus terebinthifolius Raddi) essential oil on performance, diarrhea and gut health of weanling pigs. Livest. Sci. 183, 24-27.

Helander, I.M., Nurmiaho-Lassila, E.L., Ahvenainen, R., Rhoades, J., Roller, S., 2001. Chitosan disrupts the barrier properties of the outer membrane of gram-negative bacteria. Int. J. Food Microbiol. 71, 235-244.

Huang, R.L., Yin, Y.L., Wu, G.Y., Zhang, Y.G., Li, T.J., Li, L.L., Li, M.X., Tang, Z.R., Zhang, J. Wang, B., He, J.H., Nie, X.Z., 2005. Effect of dietary oligochitosan supplementation on ileal digestibility of nutrients and performance in broilers. Poult. Sci. 84, 1383-1388.

Jonker, J.S., Kohn, R.A., Erdman, R.A., 1998. Using milk urea nitrogen to predict nitrogen excretion and utilization efficiency in lactating dairy cows. J. Dairy Sci. 81, 2681-2692.

Kramer, J.K.G., Fellner, V., Dugan, M.E.R., 1997. Evaluating acid and base catalysts in the methylation of milk and rumen fatty acids with special emphasis on conjugated dienes and total trans fatty acids. Lipids 32, 1219-1228.

Kong, M., Chen, X.G., Xing, K., Park, H.J., 2010. Antimicrobial properties of chitosan and mode of action: a state of the art review. Int. J. Food Microbiol. 144, 51-63.

McGuffey, R.K., Richardson, L.F., Wilkinson, J.I.D., 2001. Ionophores for dairy cattle: current status and future outlook. J. Dairy Sci. 84, 194-203, SE.

Mertens, D.R., 2002. Gravimetric determination of amylase-treated neutral detergent fiber in feeds with refluxing in beakers or crucibles: collaborative study. J. AOAC Int. 85, 1217-1240.

Nocek, J.E., 1988. In situ and other methods to estimate ruminal protein and energy digestibility: a review. J. Dairy Sci. 71, 2051-2069.

NRC, 2001. Nutrient Requirements of Dairy Cattle, 7th ed. National Academic Press, Washington, D.C.

Paiva, P.G., Jesus, E.F., Del Valle, T.A., Almeida, G.F., Costa, A.G.B.V.B., Consentini, C.E., Zanferari, F., Takiya, C.S., Bueno, I.C.S., Rennó, F.P., 2016. Effects of chitosan on ruminal fermentation, nutrient digestibility, and milk yield and composition of dairy cows. Anim. Prod. Sci. . http://dx.doi.org/10.1071/AN15329 (Published online)

Parodi, P.W., 2004. Milk fat in human nutrition. Aust. J. Dairy Technol. 59, 3-59.

Ruiz, R., Albrecht, G.L., Tedeschi, L.O., Jarvis, G., Russell, J.B., Fox, D.G., 2001. Effect of monensin on the performance and nitrogen utilization of lactating dairy cows consuming fresh forage. J. Dairy Sci. 84, 1717-1727.

Russell, J.B., Martin, S.A., 1984. Effects of various methane inhibitors on the fermentation of amino acids by mixed rumen microorganisms in vitro. J. Anim. Sci. 59, 1329-1338.

Sklan, D.R., Ashkenazi, R., Braun, A., Devorin, A., Tabori, K., 1992. Fatty acids, calcium soaps of fatty acids, and cotton seeds fed to high yielding cows. J. Dairy Sci. 75, 2463-2472.

Spek, J.W., Dijkstra, J., Van Duinkerken, G., Hendriks, W.H., Bannink, A., 2013. Prediction of urinary nitrogen and urinary urea nitrogen excretion by lactating dairy cattle in northwestern Europe and North America: a meta-analysis. J. Dairy Sci. 96, 4310-4322.

Xu, Y., Shi, B., Yan, S., Li, T., Guo, Y., Li, J., 2013. Effects of chitosan on body weight gain, growth hormone and intestinal morphology in weaned pigs. Asian Australas. J. Anim. Sci. 26, 1484-1489.

Yang, C.M., Russell, J.B., 1993. The effect of monensin supplementation on ruminal ammonia accumulation in vivo and the numbers of amino acid-fermenting bacteria. J. Anim. Sci. 71, 3470-3476.

Zhong, Z.M., Xing, R.G., Liu, S., Wang, L., Cai, S.B., Li, P.C., 2008. Synthesis of acyl thiourea derivatives of chitosan and their antimicrobial activities in vitro Carbohydr. Res. 343, 566-570. 